\title{
A CHINESE MOSLEM PRIMER
}

WhILE visiting important Moslem centers in the province of Honan, we found in nearly every one of the day schools kept in connection with the mosques some Arabic-Chinese text books. Some had been copied by the hand of the teacher and were being scrawled in grotesque Arabic characters by young Chinese boys. In other mosques we found lithograph copies of some of the text books. In every case the book was bilingual and the fac-simile page here reproduced from a printed copy will give the readers some idea how the Arabic characters have been modified in China. The book is entitled "Back to the True Faith Earnestly" and is really a summary of Islamic

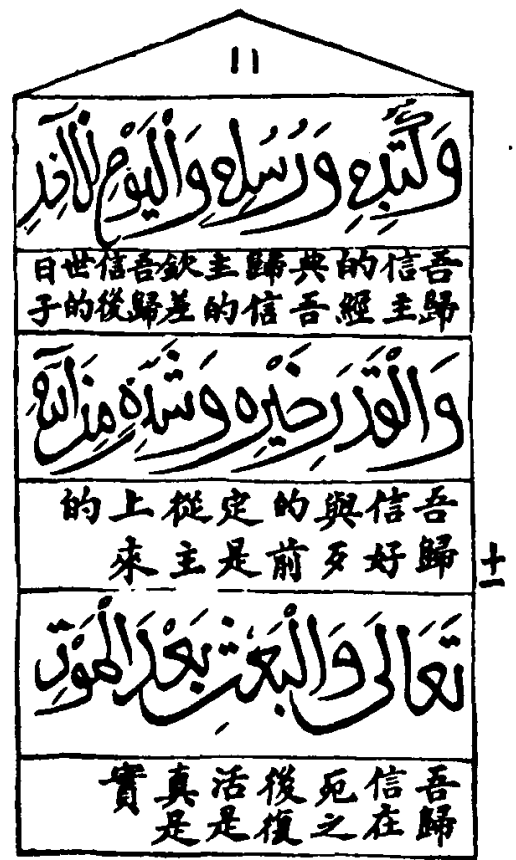

formulas and teachings. It was printed, as the title page informs us, in the third year of the Republic, eighth month $(=1914)$ at Shanghai in the street of the Adorned Heart, near the Mohammedan Mosque.

A verbatum translation of the Arabic text will interest those who have to deal with Islam in China and also indicates the character and tendency of the Primary religious education.

\section{The Text}

In the name of God the Merciful, the Compassionate. Oh God bless Mohammed and his family. Peace be unto 
you and upon you be peace and the Mercy of God and His Blessing.

A Word to Dispel Infidelity. Oh God, I take refuge in Thee from associating anyone with Thee, and I ask forgiveness from Thee of that which I know or do not know. Verily Thou are the Knower of the Unseen. And I say that there is no God but God: Mohammed is the Apostle of God.

The Word of Witness. I witness that there is no God but God only and that He has no companion and I witness that Mohammed is His Servant and His Apostle.

A Good Word. There is no God but God: Mohammed is the Apostle of God. [These same words are repeated in Persian beneath which is a Chinese text; it is remarkable that in nearly all Moslem literature in China, Persian as well as Arabic is used.] The glorious faith. I believe in God as $\mathrm{He}$ is in His names and attributes, and $\mathrm{I}$ receive all his ordinances. Exposition of the Faith. I have believed in God and His Angels and His Book and His Apostle and the Last Day, and the destiny of good and evil from God Most High, and the Resurrection after Death.

A Word of Adoration. Praise be to God and glory to Him and there is no god but God. God is Great: there is no strength and no power save in God the High and the Mighty.

The Foundation of Faith. Faith is the confession by the lips and the belief in the heart. The Ordinances of Faith. Know that the ordinances of Faith consist of six things, five for this world and one for the other. As for those that concern this world, the first is that it is not permitted for a Moslem to kill a Moslem without a just cause; second, it is not permitted for a Moslem to take the property of a Moslem unrighteously; third, it is not permitted for a Moslem to think evil of a Moslem; and the fourth, it is not permitted for a Moslem to transgress the rights of a fellow Moslem; and the fifth, it is not permitted for a Moslem to take the children of another Moslem into bondage. Now as for that which concerns the other world, it is necessary for a Moslem to know surely no Moslem shall forever abide in the Fire. 
Conditions of the Faith. Know that the conditions of the faith are of six kinds. The first is that thou shall believe in the Unseen, and secondly, that thou shalt know that the knowledge of the Unseen belongs only to God; the third is that thou shalt count as allowable that which God has permitted; the fourth is that thou shalt count as prohibited that which God has forbidden; the fifth is that thou shalt stand in awe of the punishment of God; and the sixth is that thou shalt hope in God's Mercy.

The Word of Reply in the Grave. Said the Prophet, upon Him be praise, when a dead person is buried there come to him two black angels of fierce countenance, one of whom is called Al-Munkar and the other, Nakir, and they interrogate the servant according to the following words: "Who is thy Lord, and Who is thy Prophet, and What is thy Religion, and What is thy Book, and Who is thy religious leader, and Who are thy Brethren, and What is thy Kibla?" Now if the dead person belongs to the Happy Ones he is able to give a satisfactory reply, saying, "My Lord is God, and my Prophet is Mohammed, the Apostle of God, and my religion is Islam, and my book is the Furqan (one of the names of the Koran) and my religious guide is the Koran, and my brethren are the True Believers and my Kibla is the Kaaba." They will say to him: "Sleep on like the sleep of the bride, for thy grave is one of the gardens of Paradise." But if the dead be one of the Wretched Ones, he is not able to answer correctly and so they say to him: "Thou hast not known and thou hast not read, therefore thy grave is like one of the pits of Hell." And they will torment him with Pillars of Fire.

We take refuge in God from our Sin. Written in the year of the Hijra 1332.

S. M. Z. 